\title{
Measurement of nitrate and ammonium uptake at ambient concentrations in oligotrophic waters of the North-East Atlantic Ocean
}

\author{
Andrew Rees*, Malcolm Woodward, Ian Joint \\ NERC Centre for Coastal and Marine Sciences, Plymouth Marine Laboratory, Prospect Place, The Hoe, Plymouth PL1 3DH, \\ United Kingdom
}

\begin{abstract}
Nitrate and ammonium measurements at low (4 to $650 \mathrm{nmol} \mathrm{N} \mathrm{dm}{ }^{-3}$ ) nanomolar concentrations have been combined with ${ }^{15} \mathrm{~N}$-nitrogen tracer experiments to determine uptake rates in oligotrophic regions of the NE Atlantic during the summer of 1996 between $50^{\circ}$ and $36^{\circ} \mathrm{N}$ along the $20^{\circ} \mathrm{W}$ meridian. The highest nutrient and chlorophyll concentrations were measured at the north of the transect, where the nitrate

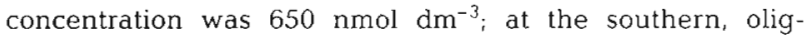
otrophic stations, nitrate concentration was ca $4 \mathrm{nmol} \mathrm{dm}-3$ Nitrate uptake has been determined at concentrations of nitrate (ambient plus added ${ }^{15} \mathrm{~N}$ tracer) as low as $7 \mathrm{nmol} \mathrm{N}$ $\mathrm{dm}^{-3}$. Nitrate uptake rate versus concentration along the transect can be described by a hyperbolic curve with parameter values $\rho_{\max }=2.77 \mathrm{nmol} \mathrm{N} \mathrm{dm}{ }^{-3} \mathrm{~h}^{-1}$ and $K_{\mathrm{NO}_{3}}=20 \mathrm{nmol} \mathrm{N}$ $\mathrm{dm}^{-3}$. Along the transect, there was a decrease in the $f$-ratio from 0.39 to 0.02 and in the relative preference index for nitrate from 0.7 to 0.1 . There was no direct indication of ammonium inhibition of nitrate uptake. The observed range in nitrate concentration of 2 orders of magnitude had the greatest influence over the interaction between ammonium concentration and nitrate uptake. There was an exponential decrease in nitrate uptake rate with increases in the ratio of ammonium:nitrate concentration.
\end{abstract}

KEY WORDS: ${ }^{15} \mathrm{~N}$ uptake $\cdot$ Oligotrophic $\cdot$ Nanomolar nitrate/ ammonium $\cdot f$-ratio

Nitrate and ammonium concentrations in the oligotrophic oceans are typically less than $100 \mathrm{nmol} \mathrm{dm}^{-3}$. In contrast to carbon uptake studies, the measurement of nutrient uptake at very low nutrient concentration levels has been limited by the lack of suitable methodologies. Many studies have measured nutrient uptake at concentrations greater than 50 to $100 \mathrm{nmol} \mathrm{N} \mathrm{dm}^{-3}$ (the typical detection limits for autoanalysis) and a

•E-mail:a.rees@ccms.ac.uk number of algorithms have been applied to describe kinetic parameters and concentration dependent uptake rates for large areas of the world's oceans (e.g. Sahlsten 1987, Tamminen 1995. Harrison et al. 1996, Slawyk et al. 1997). However, measurements for nitrate and ammonium uptake under severe oligotrophic conditions have been hampered by the absence of reliable information on their relative concentrations.

Although sensitive methods have been developed to measure nitrate (Garside 1982) and ammonium (Jones 1991) at low nanomolar concentrations, there are no reports of the simultaneous use of these methods in conjunction with tracer experiments, although their potential has been recognised (Eppley et al. 1990, McCarthy et al. 1992, Rees et al. 1995). Determinations at ambient nitrate and ammonium concentration are essential to fully understand phytoplankton nitrogen dynamics, and in particular the inhibition by ammonium of nitrate uptake. Inhibition occurs at a wide range of ammonium concentrations, including nanomolar (Wheeler \& Kokkinakis 1990, Harrison et al. 1996, Elskens et al. 1997); however Collos (1997) has reported, from a literature review of 76 studies, that $63 \%$ described covariation between ammonium and the assimilation of nitrate. Harrison et al. (1996), in recognising the limits of knowledge of nitrogen dynamics, described uptake kinetics for nitrate and ammonium at nanomolar concentrations. However, due to the inadequate detection limits of traditional ammonium analysis, in a number of cases they had to describe uptake or inhibition kinetics at unknown ambient concentrations plus added ammonium.

Flynn et al. (1997) modelled the interaction between ammonium and nitrate at concentrations which are typical of oceanographic concentrations; however, it 
has been impossible to test the model predictions in the laboratory and, due to methodological insensitivities, to validate in the field. This paper describes a small number of data gathered during a recent cruise to the NE Atlantic where the analysis of nitrate and ammonium concentrations were made to nanomolar concentrations (detection limit $2 \mathrm{nmol} \mathrm{N} \mathrm{dm}{ }^{-3}$ ) in parallel with uptake experiments using the ${ }^{15} \mathrm{~N}$ tracer technique. The uptake of nitrate is described at ambient concentrations as low as $4 \mathrm{nmol} \mathrm{N} \mathrm{dm}^{-3}$ and is related to ammonium at concentrations of 44 to $110 \mathrm{nmol} \mathrm{N} \mathrm{dm}^{-3}$.

Methods. The positions of the stations along the $20^{\circ} \mathrm{W}$ meridian are shown in Table 1 . Water samples were collected before dawn from depths approximating to the $33 \%$ irradiance level using $10 \mathrm{dm}^{3}$ Niskin bottles on a profiling CTD rosette and using a $30 \mathrm{dm}^{-3}$ go-flo (gf) bottle on 9 July. Nutrient concentrations were analysed within $1 \mathrm{~h}$ of sample collection. Nitrate was analysed by 1 of 2 methods depending on concentration. A Technicon autoanalyser using methods described by Brewer \& Riley (1965) was used when ambient nitrate was $>100 \mathrm{nmol} \mathrm{N} \mathrm{dm}^{-3}$ and a chemiluminescent method (Garside 1982) was applied when concentrations were below this concentration. Ammonium concentration was determined using the fluorometric method described by Jones (1991).

The original protocol for ${ }^{15} \mathrm{~N}$ tracer experiments (Dugdale \& Goering 1967) recommended the addition of tracer at approximately $10 \%$ of ambient concentration. In oligotrophic conditions, it has been recommended that additions should be made at the detection limits of the nutrient analysis system (McCarthy et al. 1992, IOC 1996). In this study, we made our lowest additions at $3 \mathrm{nmol} \mathrm{N} \mathrm{dm}^{-3}$ (Stn $97 \mathrm{only}$ ) and at $5 \mathrm{nmol} \mathrm{N} \mathrm{dm}^{-3}$, the remainder in the range 10 to $70 \mathrm{nmol} \mathrm{N} \mathrm{dm}^{-3}$ (Table 1). ${ }^{15} \mathrm{~N}-\mathrm{NO}_{3}$ and ${ }^{15} \mathrm{~N}-\mathrm{NH}_{4}$ were added to one each of two $2 \mathrm{dm}^{3}$ seawater samples which had been dispensed into clear polycarbonate bottles, prepared to JGOFS standards (IOC 1994). The bottles were transferred to an on-deck incubator, which simulated irradiance at $33 \%$ surface irradiance using a blue screen chosen for its spectral characteristic; temperature was controlled using a continuous flow of seawater from ca $2.5 \mathrm{~m}$ depth. The samples were incubated for $<4 \mathrm{~h}$, centred around local mid-day. The experiments were terminated by filtering through $47 \mathrm{~mm}$ GF/F filters (Whatman Ltd) and the filters were frozen until return to the laboratory. Analysis of particulate nitrogen and atom $\%{ }^{15} \mathrm{~N}$ were made by continuous flow mass spectrometry (Europa Scientific Ltd) using methods described by Barrie et al. (1989) and Owens \& Rees (1989). Rates of uptake ( $\rho N)$ were calculated from the equations of Dugdale \& Goering (1967).

Chlorophyll concentration in 3 size fractions was measured by filtering $0.1 \mathrm{dm}^{3}$ sub-samples of the seawater used in the above experiments through a series of 3 polycarbonate filters $(5.0,2.0$ and $0.2 \mu \mathrm{m}$ ) as described by Joint \& Pomroy (1983) for fluorometric chlorophyll analysis according to Holm-Hansen et al. (1965).

Results. Analytical precision: Measurements are at the lower range of sensitivity for both mass spectrometer and nutrient analyses but analytical precision was not compromised. Quality control of the nutrient analyses was conducted to a standard decreed by participation in the QUASIMEME project (Aminot et al. 1997), and the precision of all analyses was better than $5 \%$. Calculation of $\rho N$ requires values for the sample particulate nitrogen content and the ${ }^{15} \mathrm{~N}$ atom $\%$, both of which were obtained from the mass spectrometer. Results from a calibration of the instrument are shown in Fig. 1. Urea standards were analysed in the range 0.05 to $1.2 \mu \mathrm{mol} \mathrm{N}$. The mean nitrogen content of the samples was $0.7 \mu \mathrm{mol}$ and the minimum was $0.11 \mu \mathrm{mol}$. Therefore, the nitrogen content of the samples from the North Atlantic were analysed at concentrations where there was a linear relation between nitrogen content and the mass spectrometer output $\left(\mathrm{r}^{2}=0.99\right)$. High precision was

Table 1. Station location and sample depth for nitrogen uptake experiments during July 1996. For each station, ambient nitrate and ammonium concentrations are listed, with the tracer addition as a percentage of ambient concentration

\begin{tabular}{|c|c|c|c|c|c|c|c|}
\hline Stn & Date & Position & $\begin{array}{l}\text { Depth } \\
(\mathrm{m})\end{array}$ & $\begin{array}{l}\text { Ambient } \mathrm{NO}_{3}^{-} \\
\text {(nmol } \mathrm{N} \mathrm{dm}^{-3} \text { ) }\end{array}$ & $\%{ }^{15} \mathrm{~N}-\mathrm{NO}_{3}{ }^{-}$ & $\begin{array}{l}\text { Ambient } \mathrm{NH}_{4}{ }^{+} \\
\left(\mathrm{nmol} \mathrm{N} \mathrm{dm}{ }^{-3}\right)\end{array}$ & $\%{ }^{15} \mathrm{~N}-\mathrm{NH}_{4}{ }^{+}$ \\
\hline 47 & $7 \mathrm{Jul}$ & $50.3^{\circ} \mathrm{N}, 20.3^{\circ} \mathrm{W}$ & 10 & 650 & 11 & 110 & 9 \\
\hline 49 & $8 \mathrm{Jul}$ & $47.0^{\circ} \mathrm{N}, 20.0^{\circ} \mathrm{W}$ & 10 & 17 & 290 & 81 & 12 \\
\hline Gf & $9 \mathrm{Jul}$ & $44.5^{\circ} \mathrm{N}, 19.7^{\circ} \mathrm{W}$ & 10 & 8 & 63 & 65 & 8 \\
\hline 53 & $10 \mathrm{Jul}$ & $40.6^{\circ} \mathrm{N}, 19.4^{\circ} \mathrm{W}$ & 10 & 4 & 125 & 66 & 15 \\
\hline 55 & $11 \mathrm{Jul}$ & $37.0^{\circ} \mathrm{N}, 19.0^{\circ} \mathrm{W}$ & 25 & 9 & 56 & 44 & 11 \\
\hline 67 & $13 \mathrm{JuI}$ & $36.9^{\circ} \mathrm{N}, 19.2^{\circ} \mathrm{W}$ & 30 & 7 & 143 & 67 & 15 \\
\hline 90 & $17 \mathrm{Jul}$ & $36.3^{\circ} \mathrm{N}, 19.2^{\circ} \mathrm{W}$ & 25 & 6 & 167 & 80 & 13 \\
\hline 97 & $18 \mathrm{Jul}$ & $36.1^{\circ} \mathrm{N}, 19.2^{\circ} \mathrm{W}$ & 25 & 5 & 60 & 55 & 5 \\
\hline
\end{tabular}




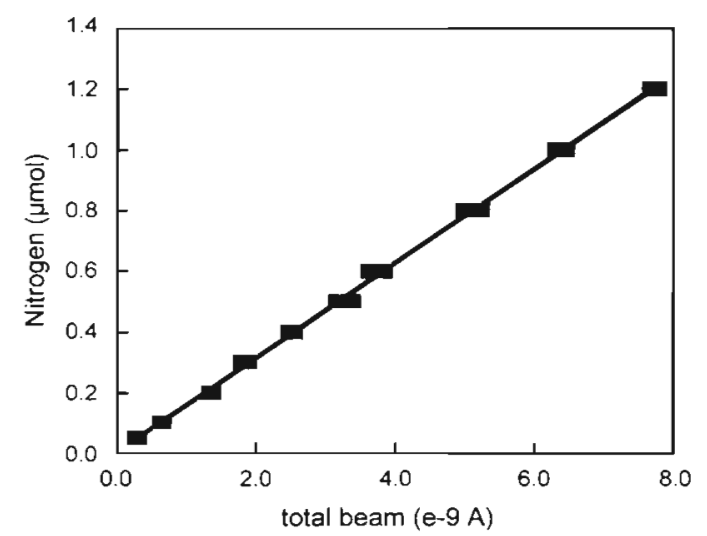

Fig. 1. Calibration curve for continuous flow isotope-ratio mass spectrometer response to urea standards in the concentration range 0.05 to $1.2 \mu \mathrm{mol}$ nitrogen. Five replicates were analysed at each standard addition $\left(\mathrm{r}^{2}=0.99\right)$

obtained with a coefficient of variation of atom $\%$ determination better than $2.37 \%$.

Transect from $50^{\circ}$ to $36^{\circ} \mathrm{N}$ : The conditions sampled along the transect changed from relatively high nutrient and chlorophyll concentration to oligotrophy. Nitrate concentrations changed from $650 \mathrm{nmol} \mathrm{N} \mathrm{dm}^{-3}$ at $50.3^{\circ} \mathrm{N}$ to $4 \mathrm{nmol} \mathrm{N} \mathrm{dm}^{-3}$ at $40.6^{\circ} \mathrm{N}$, ammonium concentrations varied between 110 and $44 \mathrm{nmol} \mathrm{N} \mathrm{dm}{ }^{-3}$ and chlorophyll concentration from $1.27 \mu \mathrm{g} \mathrm{dm}^{-3}$ to a minimum of $0.05 \mu \mathrm{g} \mathrm{dm}{ }^{-3}$ at the southern stations. Nitrate and ammonium uptake were measured at the stations listed in Table 1. Uptake rates are plotted against the total nitrate or ammonium available to the phytoplankton, i.e. the ambient concentration plus the nitrate or ammonium added as tracer. Fig. 2a shows the $\mathrm{NNO}_{3}$ at each station in relation to the nitrate concentration in the experimental bottles. Although the data cannot be used to establish uptake kinetics since these are results obtained from different stations with individual phytoplankton assemblages, the data do fit a hyperbolic function, comparable to a typical Michaelis-Menten curve. The parameter values from this curve are $\rho_{\max }=2.77 \mathrm{nmol} \mathrm{N} \mathrm{dm}^{-3} \mathrm{~h}^{-1}$ and $K_{\mathrm{NO}_{3}}=$ $20 \mathrm{nmol} \mathrm{N} \mathrm{dm}^{-3}$; these values are very similar to those published by Harrison et al. (1996) for the North Atlantic.

At very low nitrate concentrations $\left(<70 \mathrm{nmol} \mathrm{dm}{ }^{-3}\right)$, the relationship between uptake rate and nitrate concentration is linear (Fig. 2b) with nitrate concentration, explaining $83 \%$ of the variance in nitrate uptake rate following a logarithmic transformation of both variables. The equation of the fitted line is $\log _{10} \rho \mathrm{NO}_{3}=$ $1.416 \log _{10} \mathrm{NO}_{3}-2.2321$ and there is a positive intercept of the abscissa at $5 \mathrm{nmol} \mathrm{N} \mathrm{dm}^{-3}$. Ammonium uptake rate did not appear to be dependent on ammo-
Fig. 2. Data obtained between $50^{\circ}$ and $36^{\circ} \mathrm{N}$ along the $20^{\circ} \mathrm{W}$ meridian during July 1996 are plotted as (a) nitrate uptake $\left(\rho \mathrm{NO}_{3}\right)$ versus nitrate concentration $\left(\mathrm{NO}_{3}\right)$, (b) $\log$ transformation of $\mathrm{\rho NO}_{3}$ versus $\mathrm{NO}_{3}$, at concentrations $<70 \mathrm{nmol} \mathrm{N} \mathrm{dm}^{-3}$, (c) $\mathrm{NH}_{4}$ versus $\mathrm{NH}_{4}$, (d) $\mathrm{PNO}_{3}$ versus $\mathrm{NH}_{4} . \mathrm{NO}_{3}$ and $\mathrm{NH}_{4}$ concentrations are the sum of ambient plus ${ }^{15} \mathrm{~N}$ added as tracer. Error bars were propagated through the rate equation based on a maximum $5 \%$ coefficient of variation $(\mathrm{CV}=$ standard deviation $\div$ mean) on $\mathrm{NO}_{3}$ and $\mathrm{NH}_{4}$ analyses and from the standard deviation of ${ }^{15} \mathrm{~N}$ atom $\%$ based on replicate mass spectrometer samples
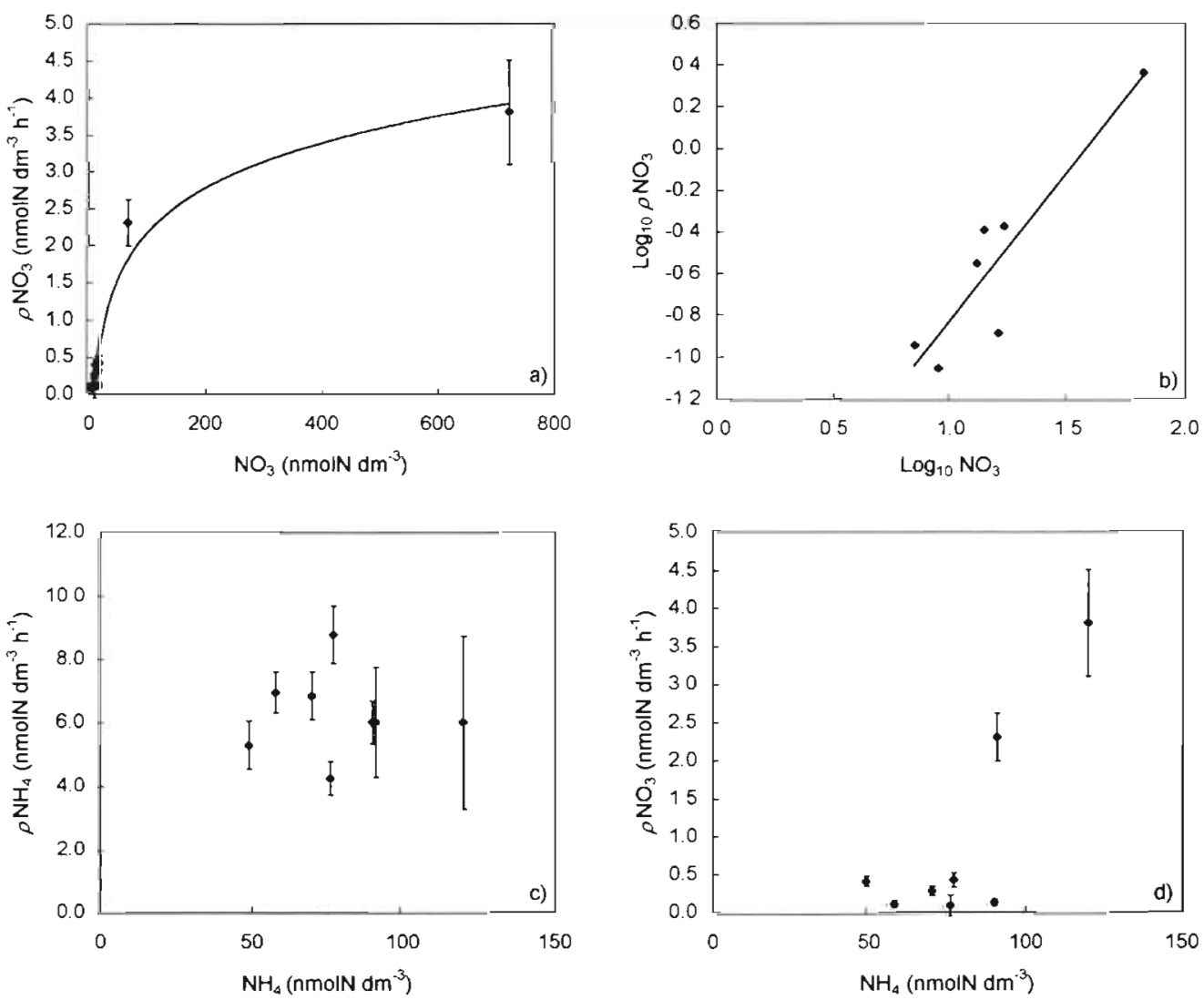
nium concentration (Fig. $2 \mathrm{c}$ ) but there did appear to be a positive correlation between $\mathrm{\rho NO}_{3}$ and ammonium concentration (Fig. 2d). However, this correlation was largely explained by the influence of the high values for nitrate concentration of 722 and $67 \mathrm{nmol} \mathrm{N} \mathrm{dm}^{-3}$ at Stns 47 and 49 respectively; these stations also had the highest ammonium concentrations. If these 2 stations are excluded it is clear that there is no significant relationship between nitrate uptake and ammonium concentration.

Discussion. The observed variations in nitrate uptake along the transect from nutrient replete conditions in the north to severe oligotrophic conditions in the south offer new insights and parameter values which can be incorporated into models of the North Atlantic. Although these data were not obtained in typical kinetic experiments, the relationship between nitrate uptake and nitrate concentration at different stations approximates well to Michaelis-Menten kinetics (Fig. 2a), which are commonly used in plankton models to describe the uptake of nitrogen (Fasham et al. 1990, Haney \& Jackson 1996). The parameters obtained are similar to those previously published for oligotrophic waters (Sahlsten 1987. Harrison et al. 1996).

In this paper, we have applied sensitive methods to determine nitrate and ammonium concentrations at very low nanomolar concentrations and have been able to measure uptake rates at previously unrecorded concentrations. The data help to reduce uncertainties regarding nitrate uptake at very low concentrations. McCarthy et al. (1992) described a linear relation between $\mathrm{\rho NO}_{3}$ and $\mathrm{NO}_{3}$ at concentrations between approximately 25 and $65 \mathrm{nmol} \mathrm{N} \mathrm{dm}^{-3}$. Extrapolation of this curve suggests that nitrate uptake would cease at the intercept value of $16 \mathrm{nmol} \mathrm{N} \mathrm{dm}^{-3}$. This implies that either a threshold for nitrate uptake exists or that there was an initial sigmoid relationship which the

Table 2. Percentage contribution of the nano- and picoplankton $(<5.0 \mu \mathrm{m})$ to total chlorophyll concentration: $f$-ratio $\left(=\rho \mathrm{NO}_{3} / \Sigma \rho \mathrm{N}\right)$ and the relative preference index $\left(\mathrm{RPI}_{\mathrm{NO}_{3}}=f\right.$ ratio/ $\left.\left\{\left[\mathrm{NO}_{3}\right],[\Sigma \mathrm{N}]\right\}\right)$ at the irradiance of $33 \%$ of that at the sea surface. nd: no data

\begin{tabular}{|ccccc|}
\hline Stn & $\begin{array}{c}\text { Chlorophyll } \\
\left(\mu \mathrm{g} \mathrm{dm}^{-3}\right)\end{array}$ & $\begin{array}{c}\text { Chlorophy]l } \\
(\%<5.0 \mu \mathrm{m})\end{array}$ & $f$-ratio & $\mathrm{RPI}_{\mathrm{NO}_{3}}$ \\
\hline 47 & 1.27 & 30 & 0.39 & 0.5 \\
49 & 0.52 & 22 & 0.28 & 1.3 \\
$\mathrm{Gf}$ & 0.32 & 37 & 0.04 & 0.2 \\
53 & 0.07 & 71 & 0.02 & 0.2 \\
55 & 0.06 & 75 & 0.07 & 0.3 \\
67 & 0.05 & 75 & 0.04 & 0.2 \\
90 & nd & nd & 0.02 & 0.1 \\
97 & nd & nd & 0.02 & 0.1 \\
& & & & \\
\hline
\end{tabular}

data of McCarthy et al. (1992) were not able to resolve. Fig. $2 b$ demonstrates that nitrate uptake does occur at nitrate concentrations $<16 \mathrm{nmol} \mathrm{N} \mathrm{dm}^{-3}$ and that the threshold, if it exists, is close to $5 \mathrm{nmol} \mathrm{N} \mathrm{dm}^{-3}$. However, these data cannot exclude the possibility that nitrate uptake occurs at ambient nitrate concentrations lower than $5 \mathrm{nmol} \mathrm{N} \mathrm{dm}^{-3}$ and that nitrate uptake may be best described by a sigmoid curve. In either case, it is clear that phytoplankton assemblages in the North Atlantic have extremely high affinities for nitrate.

There were changes in the size of the dominant phytoplankton groups along the transect, with an overall increase in the proportion of phytoplankton smaller than $5.0 \mu \mathrm{m}$ (Table 2) from north to south. This may have been due to sampling of different biogeochemical regimes and/or may indicate several stages during the seasonal succession. Two measures of the importance of nitrate to phytoplankton, the f-ratio (Dugdale \& Goering 1967) and the relative preference index (RPI) for nitrate $\left(\mathrm{RPI}_{\mathrm{NO}_{3}}\right.$. McCarthy et al. 1977), declined along the transect, indicating the increased importance of ammonium for phytoplankton production. The RPI was first introduced by McCarthy et al. (1977) as a measure of the nitrogen sufficiency of the environment; they suggested that preference for nitrate would be indicated by values of $\mathrm{RPI}_{\mathrm{NO}_{3}}$ equal to or greater than unity. Recently Dortch (1990) and Stolte \& Riegman (1996) have emphasised the need for caution in the use of the RPI and that it should not be used as an indicator of phytoplankton preference for a nitrogen species because the index is very dependant on nutrient concentrations. In support of this argument, we have found a positive correlation $\left(\mathrm{r}^{2}=0.70\right)$ for the least squares linear regression of $\mathrm{RPI}_{\mathrm{NO}_{3}}$ on $\mathrm{NH}_{4}: \mathrm{NO}_{3}$ ratio $\left(\mathrm{RPI}_{\mathrm{NO}_{3}}=-0.049 \mathrm{NH}_{4}: \mathrm{NO}_{3}+0.532\right)$.

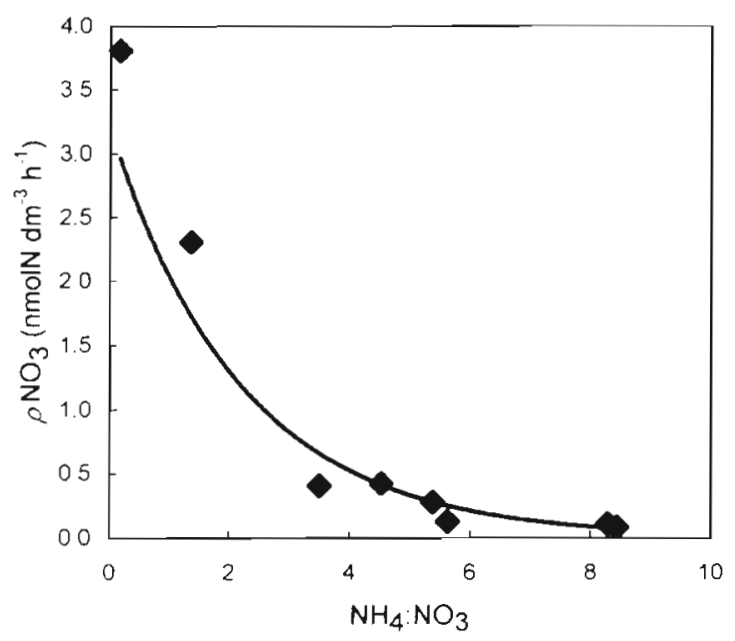

Fig. 3. The relationship between $\rho \mathrm{NO}_{3}$ and the $\mathrm{NH}_{4}: \mathrm{NO}_{3}$ concentration ratio. The equation of the fitted curve is $\mathrm{pNO}_{3}=$ $3.19 e^{-0.43 \mathrm{NH}_{4} \mathrm{NO}_{3} !}\left(\mathrm{r}^{2}=0.93\right)$ 
The preference of phytoplankton for ammonium over nitrate is well documented and extends over the full spectrum of nitrogen concentrations (Harrison et al. 1996). Ammonium has also often been demonstrated to inhibit nitrate uptake in natural assemblages; for example, Wheeler \& Kokkinakis (1990) found complete inhibition of nitrate uptake by ammonium concentrations of 100 to $300 \mathrm{nmol} \mathrm{N} \mathrm{dm}^{-3}$ in the subarctic Pacific. Generally, ammonium inhibition is considered to apply at higher concentration; Tamminen (1995) reported significant inhibition of nitrate uptake by ammonium concentrations of $350 \mathrm{nmol} \mathrm{N}$ $\mathrm{dm}^{-3}$ when the ambient nitrate concentration was $4300 \mathrm{nmol} \mathrm{N} \mathrm{dm}^{-3}$.

The data presented here, although not derived from kinetic experiments, suggest that comparisons of different assemblages can provide valuable information on both the kinetics of nitrate uptake and of the effect of varying $\mathrm{NH}_{4}: \mathrm{NO}_{3}$ concentration ratios on $\mathrm{\rho NO}_{3}$. Fig. 3 shows the influence of the ammonium:nitrate ratio on nitrate uptake at values ranging from 0.2 (120 nmol $\mathrm{N} \mathrm{dm}^{-3} \mathrm{NH}_{4}$ when the $\mathrm{NO}_{3}$ was $722 \mathrm{nmol} \mathrm{N}$ $\mathrm{dm}^{-3}$ ) to 8 ( $58 \mathrm{nmol} \mathrm{N} \mathrm{dm}^{-3} \mathrm{NH}_{4}$ to $7 \mathrm{nmol} \mathrm{N} \mathrm{dm}{ }^{-3} \mathrm{NO}_{3}$ ). The relatively small change in ammonium concentration ( 120 to $49 \mathrm{nmol} \mathrm{N} \mathrm{dm}^{-3}$ ) was accompanied by a change of 2 orders of magnitude in nitrate. There was no direct evidence for ammonium inhibition and the greatest influence on nitrate uptake was the large decrease in nitrate concentration.

These data have quantified the relationship between nitrate uptake rate and nitrate and ammonium at concentrations typical of summer conditions in the $\mathrm{NE}$ Atlantic Ocean. The data should be useful in refining models of plankton production in 2 specific areas. Pos. itive uptake of nitrate has been measured at concentrations of $5 \mathrm{nmol} \mathrm{N} \mathrm{dm}^{-3}$, hence defining the upper limit for any threshold nitrate uptake. Secondly, an exponential relationship is developed which describes nitrate uptake at changing $\mathrm{NH}_{4}: \mathrm{NO}_{3}$ ratios.

Acknowledgements. We particularly appreciate the advice given on an earlier version of this manuscript by Marc Elskens and Carol Robinson and would like to thank Kirsten Donald for her assistance in the analysis of chlorophyll data. This work forms a part of the research of The Dynamics of Marine Ecosystems (DYME) Research Project 1 of the Centre for Coastal and Marine Sciences Plymouth Marine Laboratory, a component of the Natural Environment Research Council. This work was funded in part by the PRIME Thematic Programme of the Natural Environment Research Council (grant GST/02/1055) and is PRIME contribution no. 120.

\section{LITERATURE CITED}

Aminot A, Kirkwood D, Carlberg S (1997) The QUASIMEME laboratory performance studies (1993-1995): overview of the nutrients section. Mar Pollut Bull 35:28-41
Barrie A, Davies JE, Park AJ, Workman CT (1:89) Continuous-flow stable isotope analysis for biologists. Spectroscopy $4: 42-52$

Brewer PG, Riley JP (1965) The automatic cetermination of nitrate in seawater. Deep-Sea Res 12:765-772

Collos Y (1997) Covariation of ammonium and nitrate uptake in several marine areas: calculation artefact ar indication of bacterial uptake? Preliminary results from a review of 76 studies. In: Dehairs F, Elskens M, Goeyens L (eds) Integrated Marine System Analysis. Vrije Universiteit Brussel, Brussels, p 121-138

Dortch Q (1990) The interaction between ammonium and nitrate uptake in phytoplankton. Mar Ecoll Prog Ser 61. $183-201$

Dugdale RC, Goering JJ (1967) Uptake of nerr and regenerated forms of nitrogen in primary productivity. Limnol Oceanogr 12:196-206

Elskens M, Baeyens W, Goeyens L (1997) Contribution of nitrate to the uptake of nitrogen by phytoflenkton in an ocean margin environment. Hydrobiologia 353:139-152

Eppley RW, Garside C, Renger EH, Orellana $\Xi$ (1990) Variability of nitrate concentration in nitrogen-depleted subtropical surface waters. Mar Biol 107:53-60

Fasham MJR, Ducklow HW, McKelvie SM (1990) A nitrogen based model of plankton dynamics in the mceanic mixed layer. J Mar Res 48:591-639

Flynn KJ, Fasham MJR, Hipkin CR (1997) Modelling the interactions between ammonium and nitrete uptake in marine phytoplankton. Philos Trans R Sor Lond B 352 : $1625-1645$

Garside C (1982) A chemiluminescent techrique for the determination of nanomolar concentrations of nitrate and nitrite in seawater. Mar Chem 11:159-16?

Haney JD, Jackson GA (1996) Modeling phytcplankton growth rates. J Plankton Res 18:63-85

Harrison WG, Harris LR, Irwin BD (1996) The kinetics of nitrogen utilisation in the oceanic mixed layer: nitrate and ammonium interactions at nanomolar concentrations. Limnol Oceanogr 41:16-32

Holm-Hansen $O$, Lorenzen $C J$, Holmes RW, Sturickland JDH (1965) Fluorometric determination of chlorophyll. J Cons Int Explor Mer 30:3-15

IOC (1996) Protocols for the Joint Global Ocean Flux Study (JGOFS) core measurements. Man Guides 10C, UNESCO, Paris

Joint IR, Pomroy A.J (1983) Production of picmplankton and small nanoplankton in the Celtic Sea. Mar Fiol 77:19-27

Jones RD (1991) An improved fluorescence rethod for the determination of nanomolar concentration.si of ammonium in natural waters. Limnol Oceanogr 36:814 819

McCarthy JJ, Taylor WR, Taft JL (1977) Nitrogemous nutrition of the plankton in the Chesapeake Bay. 1. Vutrient availability and phytoplankton preferences. Limnol Oceanogr 22:996-1011

McCarthy JJ, Garside C, Nevins JL (1992) Nitrate supply and phytoplankton uptake kinetics in the euphotic layer of a Gulf Stream warm-core ring. Deep-Sea Res 39:393-403

Owens NJP, Rees AP (1989) Determination of zitrogen-15 at submicrogram levels of nitrogen using atomated continuous-flow isotope ratio mass spectrometry. Analyst 114: $1655-1657$

Rees AP, Owens NJP, Woodward EMS (1995) Phytoplankton nitrogen assimilation at low nutrient concentrations in the NW-Mediterranean Sea (July 1993). In: Martin JM, Barth $\mathrm{H}$ (eds) Water Pollution Reports, No. 32. Enropean Commission, Brussels, p 141-148

Sahlsten E (1987) Nitrogenous nutrition in the euphotic zone 
of the Central North Pacific Gyre. Mar Biol 96:433-439

Slawyk G, Coste B, Collos Y. Rodier M (1997) Isotopic and enzymatic analyses of planktonic nitrogen utilisation in the vicinity of Cape Sines (Portugal) during weak upwelling activity. Deep-Sea Res 44:1-25

Stolte W, Riegman R (1996) The relative preference index (RPI) for phytoplankton nitrogen use is only weakly related to

Editorial responsibility: Otto Kinne (Editor),

Oldendorf/Luhe, Germany physiological preference. J Plankton Res 18:1041-1045 Tamminen $T$ (1995) Nitrate and ammonium depletion rates and preferences during a Baltic spring bloom. Mar Ecol Prog Ser 120:123-133

Wheeler PA, Kokkinakis SA (1990) Ammonium recycling limits nitrate use in the oceanic subarctic Pacific. Limnol Oceanogr 35:1267-1278

Submitted: March 9, 1999; Accepted: May 14, 1999 Proofs received from author(s): September 24, 1999 